\title{
PENGARUH PAJANAN PARTICULATE MATTER 10 (PM10) DI UDARA TERHADAP KELUHAN SISTEM PERNAPASAN MASYARAKAT DI SEKITAR PABRIK SEMEN $X$ DESA TIPAR KIDUL KECAMATAN AJIBARANG TAHUN 2018
}

\author{
Jati Firmanto $^{1}$, Mela Firdaust ${ }^{2)}$, Hikmandari ${ }^{3)}$ \\ Jurusan Kesehatan Lingkungan, Politeknik Kesehatan Kemenkes Semarang, \\ Jl.Raya Baturaden KM 12 Purwokerto, Indonesia
}

\begin{abstract}
Abstrak
Latar belakang Kegiatan industri berperan vital dalam pertumbuhan ekonomi tapi juga berdampak negatif bagi kesehatan seperti kadar debu partikulat PM10. Environmental Protection Agency dalam World Bank, mengestimasikan 90\% dari PM10 yang dikeluarkan ke udara mengandung sulfur dioksida (SO2). Dari hasil beberapa penelitian diketahui partikel debu $\left(P M_{10}\right)$ dapat mengakibatkan inflamasi pada saluran napas dan dapat memicu terjadinya asma (Darmono, 2010 dan ATSDR, 2011). Tujuan penelitian ini untuk menganalisis pengaruh pajanan $P M_{10}$ di udara terhadap keluhan sistem pernapasan. Jenis penelitian menggunakan analitik observasional. Metode yang digunakan adalah cross sectional. Sampel dalam penelitian ini yaitu 32 responden kelompok terpajan dan 32 responden kelompok tidak terpajan. Hasil penelitian menunjukkan rata - rata kadar debu $P M_{10}$ yaitu 0,16663 mg/kg/hari pada kelompok terpapar dan 0,04252 pada kelompok tidak terpapar. Sedangkan persentase responden yang memiliki keluhan sistem pernapasan yaitu sebanyak 65,6\% pada kelompok terpapar dan 34,4\% pada kelompok tidak terpapar. Simpulan dari hasil uji regresi logistic ganda yaitu variabel yang mempengaruhi keluhan system pernapasan yatu intake $P M{ }_{10}$ dengan nilai $p$ sebesar 0,048 dan riwayat penyakit pernapasan dengan nilai p 0,039 (nilai p <0,05). Saran dari hasil penelitian ini diharapkan masyarakat melakukan beberapa upaya untuk mencegah partikulat masuk kedalam rumah dan diharapkan pemerintah memonitor kualitas lingkungan secara teratur sebagai bahan pertimbangan perpanjangan izin industri.
\end{abstract}

Kata kunci : pajanan $P M_{10}$, keluhan sistem pernapasan, riwayat penyakit pernapasan

\begin{abstract}
The Influence of Particulate Matter (PM10) Exposure in Air to Community Respiratory System Complaints Around Cement Factory $X$ in Tipar Kidul Village Ajibarang District in 2018. BackgroundIndustrial activity important for economic growth but also adversely affects health such as $P M_{10}$ particulate emissions. Environmental Protection Agency in the World Bank, estimates that $90 \%$ of air-fired PM 10 contains sulfur dioxide (SO2). From the results of several studies known dust particles $\left(P M_{10}\right)$ can cause inflammation of the airways and can trigger the occurrence of asthma (Darmono, 2010 and ATSDR, 2011). The purpose of this study was to analyze the effect of $P M_{10}$ exposure in air to respiratory system complaints. This type of research uses observational analytics. The method used is cross sectional. The sample in this study were 32 respondents exposed group and 32 respondents group not exposed. The results showed that the mean intake of PM 10 was $0.16663 \mathrm{mg}$ $/ \mathrm{kg} /$ day in the exposed group and 0.04252 in the unexposed group. While percentage of respondents who have respiratory system complaints that is as much as $65.6 \%$ in the exposed group and $34.4 \%$ in the group not exposed. It is conclude based on the result of multiple logistic regression test that is variables that influence the respiratory system complaints yatu intake PM 10 with $p$ value equal to 0,048 and history of respiratory disease with $p$ value 0,039 ( $p$ value <0,05). Suggestion from the results of this study is expected to make some efforts to prevent particulate entry into the home and the government is expected to monitor the quality of the environment on a regular basis as material consideration of the extension of industrial permit.
\end{abstract}

Keywords $\quad: P M_{10}$ exposure, complaints of the respiratory system, history of respiratory diseases

${ }^{1)}$ Email :jatihpp@gmail.com

${ }^{2)}$ Email:melafirdaust.airlangga@gmail.com

${ }^{3)}$ Email:hikmandari@gmail.com 


\section{PEndahuluan}

Kegiatan industri mempunyai peran penting dalam pertumbuhan ekonomi, Meskipun industri dapat menghasilkan suatu barang yang bermanfaat bagi manusia,menimbulkan kerugian bagi lingkungan akibat pencemaran yang dihasilkan.Revolusi industri mengiringi umat manusia ke dalam peningkatan pencemaran udara yang drastic, Walaupun tidak semua pabrik menghasilkan pencemar udara karena hal ini tergantung pada bahan baku, bahan bakar, metode, efisiensi proses, dan instalasi pengontrol bahan pencemar pabrik tersebut. Pabrik-pabrik yang dapat menimbulkan pencemaran udara antara lain pabrik semen, pabrik plastik, dan pabrik karet. Pabrik kimia dalam banyak hal memungkinkan menghasilkan semua bentuk cemaran udara melalui cerobong asap pabrik. Bahan-bahan kimia beracun dari cerobong asap pabrik, dapat berbentuk gas ataupun berbentuk partikelparktikel.

Menurut Mukono (1997), konsekuensi dari proses pembangunan industri adalah meningkatnya limbah yang dikeluarkan oleh industri tersebut termasuk limbah udara yang dapat merubah kualitas udara ambien. Sektor industri memberikan sumbangsih bermakna dalam pencemaran udara di Jakarta, Bandung dan Surabaya khususnya oksida - sulfur yang mencapai lebih $60 \%$ dari total emisi unsur ini, NO2 disebarkan dalam persentase diatas $15 \%$.

Hasil penelitian pendahuluan yang salah satunya berupa wawancara diketahui bahwa hal ini juga menjadi alasan utama warga tidak pernah membuka pintu utama rumah dan jendela rumah dan memicu adanya penyakit berbasis lingkungan yang disebabkan oleh pencemaran udara. Jumlah 62 RT yang ada, terdapat 3 RT (RT 01, 07, 08) yang berdekatan secara langsung dengan industri semen karena pada bagian belakang industri tersebut tidak terdapat tembok penyekat dan hanya di batasi dengan kebun - kebun yang memiliki jarak \pm 9 meter ke lokasi industri. Ketiga RT tersebut berlokasi di tengah dan terdekat dengan industri semen dan industri kayu.Banyak beroperasi berbagai pabrik seperti kimia, semen, kayu lapis, pembangkit listrik maupun yang lainnya.Kegiatan industri tersebut potensial dalam menghasilkan bahan pencemaran udara. Industri semen berpotensi sebagai sumber pencemaran partikel (Wardhana,2001).

Kegiatan industri berperan vital dalam pertumbuhan ekonomi, tetapi juga berdampak negatif besar bagi kesehatan dan lingkungan. Salah satu dampak negatif tersebut adalah emisi partikulat di udara dari tungku industri dan industri pengolahan yang menurut penelitian Wiguna, merupakan penyumbang terbesar sekitar 51,27\%. Namun, yang menjadi perhatian penting adalah partikulat dengan ukuran di bawah 2,5 mikron
$\left(\mathrm{PM}_{10}\right)$.Hal tersebut disebabkan oleh $\mathrm{PM}_{10}$ dapat secara leluasa masuk ke dalam saluran pernapasan dan mengendap di alveoli. $\mathrm{PM}_{10}$ yang berasal dari kegiatan industri biasanya mengeluarkan berbagai material logam berat dan sulfur dioksida. Environmental Protection Agency dalam World Bank, mengestimasikan 90\% dari $\mathrm{PM}_{10}$ yang dikeluarkan ke udara mengandung sulfur dioksida ( $\mathrm{SO} 2)$.

Berbagai material tersebut dapat menyebabkan berbagai gangguan saluran pernapasan seperti infeksi saluran pernapasan akut (ISPA), kanker paruparu,penyakit kardiovaskular, kematian dini, dan penyakit paru-paru obstruktif kronis.Gangguan tersebut disebabkan oleh inflamasi dan injuri oleh pajanan $\mathrm{PM}_{10}$ yang masuk ke dalam saluran pernapasan.Suatu studi eksperimen dilakukan pada tikus Sprague-Dawley (CD) untuk melihat efek pajanan partikulat pada perubahan fisiologi sel paru-paru.Tikus yang dipajankan dengan partikulat yang telah dilarutkan dalam larutan garam mengalami peningkatan laktat dehidrogenase (LDH) pada cairan bronchoalveolar lavage (BAL) hingga mencapai sekitar $153 \%$ dari keadaan normal. Peningkatan cairan LDH menunjukkan respons inflamasi atau injuri yang diakibatkan oleh peningkatan sel netrofil.Inflamasi tersebut selanjutnya mendorong terjadi penyakit ISPA.Masyarakat yang bermukim di kawasan industri merupakan yang paling berisiko terhadap pajanan $\mathrm{PM}_{10}$ di udara, seperti masyarakat di Kecamatan Lubuk Kilangan, Kota Padang. Kecamatan ini dapat menjadi sangat berisiko karena industri semen merupakan salah satu penyumbang terbesar total emisi partikulat global.Selain itu, material yang terkandung di dalam partikulat semen seperti silika dapat dengan mudah mengganggu saluran pernapasan.

Pencemaran udara yang terakumulasi di dalam tubuh manusia menjadi risiko penyebab asma. Zat-zat yang berperan dalam pencemaran udara diantaranya $\mathrm{SO}$, $\mathrm{NO} 2, \mathrm{~Pb}, \mathrm{CO} 2$ dan $\mathrm{PM}_{10}$. Menurut Nukmat et al (2005) partikel debu terhirup $\left(\mathrm{PM}_{10}\right)$ memiliki tingkat risiko kesehatan lebih besar dibandingkan zat polutan lainnya. Partikel debu terhirup $\left(\mathrm{PM}_{10}\right)$ adalah istilah umum yang digunakan untuk menjelaskan campuran kompleks partikel aerosol yang melayang di udara dengan diameter $\leq 10$ Mikron (U.S.EPA, 2010 and Horrison, 1999). Dari hasil beberapa penelitian diketahui partikel debu $\left(\mathrm{PM}_{10}\right)$ dapat mengakibatkan inflamasi pada saluran napas dan dapat memicu terjadinya asma (Darmono, 2010; ATSDR, 2011 dan US.EPA,2010).

Kasus ISPA yang tinggi di daerah industri semen dapat dicurigai akibat kontribusi pajanan $\mathrm{PM}_{10}$ di udara.Namun, belum banyak dilakukan penelitian tentang estimasi risiko terhadap manusia dengan menggunakan karakterisasi pajanan lingkungan, antropometri, dan pola aktivitas.Hasil penelitian ini 
tidak hanya bermanfaat dalam pengendalian risiko, tetapi juga dapat digunakan sebagai kerangka ilmiah dalam pengambilan keputusan dan kebijakan dalam mengatasi masalah-masalah kesehatan dan lingkungan.

Pembangunan pabrik semen tentu tidak lepas dari masalah lingkungan.Wilayah pedesaan yang identik dengan kesejukan berubah menjadi wilayah perkotaan kecil yang mana berbagai dampak dari sebuah industri menyeruak luas.Seperti diketahui bersama bahwa kawasan industri tentu tidak lepas dengan pencemaran lingkungan.Pencemaran yang menjadi permasalahan epik ialah pencemaran udara atau lebih tepatnya polusi udara.

Tujuan penelitian ini adalah menganalisis Pengaruh Pajanan $\mathrm{PM}_{10}$ di Udara Terhadap Keluhan Sistem Pernapasan Masyarakat Di Sekitar Pabrik Semen X di Desa Tipar Kidul Kecamatan Ajibarang.

\section{BAHAN DAN METODE}

Jenis penelitian ini adalah analitik observasional dengan desain cross sectional study. Penelitian ini dilakukan untuk mengetahui pengaruhvariabel independen berupa pajanan debu $\left(\mathrm{PM}_{10}\right)$ terhadap variabel dependen yaitu keluhan sistem pernapasan pada masyarakat.Populasi dalam penelitian ini adalah seluruh masyarakat berisiko yang tinggal di sekitar pabrik semen di Desa Tipar Kidul Kecamatan Ajibarang.Sampel dipilih berdasarkan kriterian inklusi sebanyak 32 responden kelompok terpajan dan 32 responden kelompok tidak terpajan.

Pengumpulan data intake PM10 dilakukan dengan mengukur kadar partikulat PM10 di udara dengan alat dustrack, mengukur berat badan responden dengan timbangan, tinggi badan dengan microtoise dan menentukan status gizi Hasil pengukuran dianalisis dengan menggunakan soft ware analisis data yang terdiri dari univariate untuk mendeskripsikan tiap variabel, kemudian analisis multivariate menggunakan analisis regresi logistik ganda yang bertujuan untuk mengestimasi secara valid pengaruh pajanan partikel debu terhirup (intake $\mathrm{PM}_{10}$ ) dengan keluhan system pernafasan setelah dikontrol oleh variabel antara.

\section{HASIL DAN PEMBAHASAN}

\section{Gambaran Umum Lokasi Penelitian}

Ada beberapa desa yang mengelilingi industri semen X yaitu Desa Tipar dan desa Karang Bawang. Desa tersebut masing masing berjarak kurang lebih 50-100 meter dari industri semen $\mathrm{X}$.Berdasarkan Peraturan Menteri Industri No. 35 tahun 2010 tentang teknis kawasan industry menyatakan Bahwa 1).Berdampak negatif karena kegiatan Industry menghasilkan polutan dan limbah yang dapat membahayakan bagi kesehatan masyarakat.2).Jarak terhadap pemukiman yang ideal minimal 2(dua) km dari lokasi kegiatan industri.Dampak dari keadaan tersebut sudah terlihat dengan adanya keluhan warga yang merasa tidak nyaman karena adanya debu yang bersumber dari industri yang mengganggu aktifitas warga.desa yang akan di teliti yaitu desa tipar dan karang bawang.

Peneliti melakukan studi pendahuluan di lokasi peneltian dengan metode wawancara terhadap masyrakat sekitar pabrik semen $\mathrm{x}$ tentang dampak beroperasinya kegiatan pabrik, bahwa hal ini menjadi alasan utamawarga tidak pernah membuka pintu utama rumah dan jendela yang memicu adanya penyakit berbasis lingkungan yang disebabkan pencemaran udara. Dua desa tersebut berdekatan secara langsung tanpa ada tembok penyekat dan hanya di batasi dengan kebun kebun dan pohon yang memiliki jarak kurang lebih 9 meter. Kegiatan industri semen berpotensi sebagai sumber pencemaran partikel (ardhana,2001).

Penelitian terbagi menjadi 2 kelompok terpapar dan tidak terpapar. Pada kelompok terpapar ada pada ring 1,2 dan 3 dan yang tidak terpapar ada pada ring 4 dan 5 .

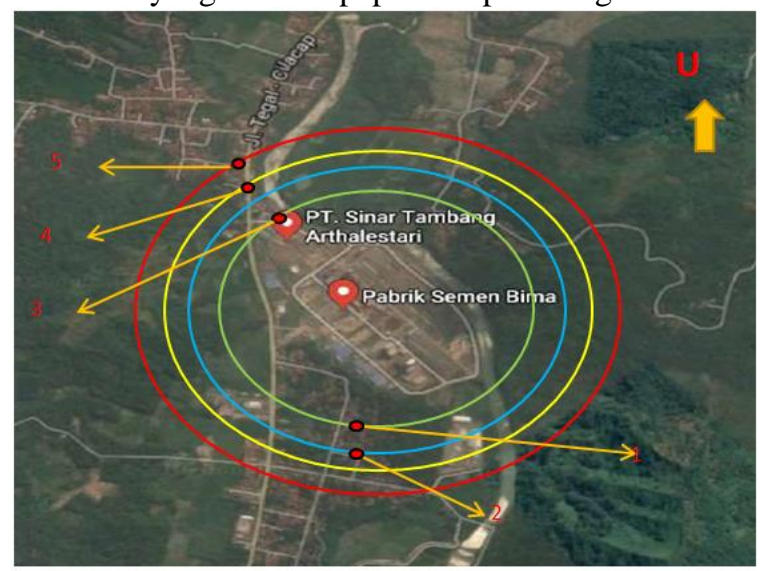

Gambar 3.1 area penelitian dan titik sampling udara (sample point)

Keterangan :

\begin{tabular}{llcc}
\hline Ring & \multicolumn{1}{c}{ Lokasi } & $\begin{array}{c}\text { Jarak } \\
(\mathbf{M})\end{array}$ & Koefisien \\
\hline Ring 1 Desa Tipar Kidul RT & $50-100$ & $0,169 \mu \mathrm{g} / \mathrm{m}^{3}$ \\
& 07/ RW 01 & \\
\hline Ring 2 Desa Tipar Kidul RT & $100-150$ & $0,108 \mu \mathrm{g} / \mathrm{m}^{3}$ \\
01 / RW 02 & & \\
\hline Ring 3 & $\begin{array}{l}\text { Desa Karang Bawang 50-100 } \\
\text { RT 08/ RW 02 }\end{array}$ & $0,104 \mu \mathrm{g} / \mathrm{m}^{3}$ \\
\hline Ring 4 Desa Karang Bawang 150-200 & $0,072 \mu \mathrm{g} / \mathrm{m}^{3}$ \\
& \\
\hline RT 09/ RW 01 & \\
\hline Ring 5 Desa Karang Bawang 200-250 & $0,040 \mu \mathrm{g} / \mathrm{m}^{3}$ \\
RT 07/ RW 01 & \\
\hline
\end{tabular}




\section{Analisa Univariat}

\section{Intake $\mathbf{P M}_{10}$}

Tabel 4.1 Distribusi Frekuensi Intake $\mathrm{PM}_{10}$

\begin{tabular}{|c|c|c|}
\hline Kelompok & $\sum_{(\mathrm{mg} / \mathrm{kg} / \mathrm{hari})}$ intake & Rata - Rata \\
\hline Terpapar & 5,3322 & 0,16663 \\
\hline Tidak Terpapar & 1,3608 & 0,04252 \\
\hline
\end{tabular}

Partikel debu terhirup $\left(\mathrm{PM}_{10}\right)$ adalah istilah umum yang di gunakan untuk menjelaskan campuran kompleks partikel aerosol yang melayang di udara.Pada penelitian ini pajanan debu di lihat dari intake partikel debu terhirup $\left(\mathrm{PM}_{10}\right)$.Intake partikel debu yang terhirup $\left(\mathrm{PM}_{10}\right)$ adalah tingkat kosentasi partikel debu terhirup $\left(\mathrm{PM}_{10}\right)$. Menurut Permenkes 1077/Menkes/Per/2011 Tentang pedoman Penyehatan Udara dalam Rumah, intake partikel debu terhirup $\left(\mathrm{PM}_{10}\right)$ yaitu sebesar $70 \mu \mathrm{g} / \mathrm{m} 3$ atau $0,07 \mathrm{mg} / \mathrm{m} 3$.Kelompok terpapar dengan jumlah responden yaitu 32 orang didapatkan hasil jumlah intake $\mathrm{PM}_{10}$ sebanyak 5,3322 dengan nilai rata rata yaitu $0,16663 \mathrm{mg} / \mathrm{kg} / \mathrm{hari}$ dan pada kelompok tidak terpapar dengan jumlah responden 32 orang didapatkan hasil jumlah intake $\mathrm{PM}_{10}$ sebanyak 1,3608 dan nilai rata-rata yaitu $0,04252 \mathrm{mg} / \mathrm{kg} / \mathrm{hari}$. Penelitian ini mendapatkan hasil bahwa pada kelompok terpapar dengan melihat nilai rata-rata sebagian besar responden menerima asupan partikel debu terhirup $\left(\mathrm{PM}_{10}\right)$ dimana nilai lebiih dari baku mutu yang sudah di tentukan yaitu $0,07 \mathrm{mg} / \mathrm{kg} / \mathrm{hari}$ dan kelompok yang tidak terpapar karena masih dibawah nilai baku mutu.

\section{Karakteristik individu}

a. Jenis Kelamin

Tabel 4.2 Persentase Jenis kelamin Responden

\begin{tabular}{lcccc}
\hline \multirow{2}{*}{$\begin{array}{c}\text { Jenis } \\
\text { kelamin }\end{array}$} & \multicolumn{2}{c}{$\begin{array}{c}\text { Kelompok } \\
\text { Terpapar }\end{array}$} & $\begin{array}{c}\text { Kelompok Tidak } \\
\text { Terpapar }\end{array}$ \\
\cline { 2 - 5 } & n & Presentase & n & Presentase \\
\hline Laki-Laki & 17 & $53,1 \%$ & 17 & $53.1 \%$ \\
\hline Perempuan & 15 & $46,9 \%$ & 15 & $46.9 \%$ \\
\hline Jumlah & 32 & $100 \%$ & 32 & $100 \%$ \\
\hline
\end{tabular}

Jenis kelamin pada kelompok terpapar dengan jumlah responden 32 orang didapatkan hasil yaitu terdapat 17 responden (53.1\%) berjenis kelamin laki - laki dan 15 responden $(46,9 \%)$ berjenis kelamin perempuan. Sedangkan pada kelompok tidak terpapar dengan jumlah responden 32 orang didapatkan hasil yaitu terdapat 17 responden $(53.1 \%)$ berjenis kelamin laki - laki dan 15 responden (46,9\%) berjenis kelamin perempuan. Pada penelitian ini jenis kelamin responden didominasi laki-laki.Secara teori laki-laki membutuhkan energi jauh lebih besar dari pada perempuan.Untuk memecahkan zat nutrisi menjadi energi pada prosese metabolisme di perlukan oksigen.Hal ini membuat laki-laki memerlukan oksigen lebih banyak dari perempuan. Menurut Pearce (2009) kebutuhan oksigen normal laki laki 4-5 lite dan pada perempuan sebesar 3-4 liter. Besarnya kebutuhan oksigen pada laki-laki berbanding lurus dengan laju respirasi.Hal ini diitunjukan pada angka default laju respirasi untuk wanitadan laki-laki pada usia 19-65 tahun masing masing $11,3 \mathrm{~m} 3 /$ hari dan 15,2 $\mathrm{m} 3 /$ hari.Besarnya laju respirasi pada laki laki membuat rentan menerima asupan partikel debu terhirup (PM10) lebih banyak dari pada perempuan. Banyaknya asupan Partikel debu (PM10) yang diterima membuat laki-laki lebih beresiko mengalami keluhan sistem pernapasan.

\section{b. Status Gizi}

Tabel 4.3 Persentase Status Gizi (IMT)

\begin{tabular}{lcccc}
\hline \multirow{2}{*}{$\begin{array}{c}\text { Jenis } \\
\text { kelamin }\end{array}$} & \multicolumn{2}{c}{$\begin{array}{c}\text { Kelompok } \\
\text { Terpapar }\end{array}$} & \multicolumn{2}{c}{$\begin{array}{c}\text { Kelompok } \\
\text { Tidak Terpapar }\end{array}$} \\
\cline { 2 - 5 } & n & Presentase & n & Presentase \\
\hline $\begin{array}{l}\text { Normal }(18,5- \\
24,99)\end{array}$ & 24 & $75 \%$ & 24 & $75 \%$ \\
\hline $\begin{array}{l}\text { Tidak normal ( } \\
<18,5 \text { atau } \geq \\
25)\end{array}$ & 8 & $25 \%$ & 8 & $25 \%$ \\
\hline $\begin{array}{l}\text { Jumlah } \\
\text { Junly }\end{array}$ & 32 & $100 \%$ & 32 & $100 \%$ \\
\hline
\end{tabular}

Status gizi di definiskan sebagai keadaan tubuh sebagai akibat dari kecukupan zat gizi yang di lihat ari hasil perhitungan indeks massa tubuh (IMT).Pada penelitian ini status gizi di kelompokan menjadi dua yaitu normal jika IMT $18,5 \leq 24,99$ dan tidak normal $<18,5 \& \geq 25$.

Hasil analisis distribusi responden berdasarkan status gizi di ketahui bahwa responden di dominasi oleh status gizi normal.Status gizi yang normal berbanding lurus dengan sistem imunitas(Oemiati,et all..,2010). Sistem imunitas adalah satu sistem dalam tubuh yang terdiri dari sel-sel yang bekerja sama secara kolektif dan terkoordinir untuk melawan benda asing yang masuk ke dalam tubuh (Carpenito,2009).Sistem imuntitas yang tidak baik menimbullkan respons peradangan pada saluran pernafasan. Respon peradangan pada saluran pernafasan dapat menimbulkan efek edema lokal pada dinding bronkiolus,sekresi mukus yang kental di dalam lumen yang berakibat pada penyempitan saluran napas yang pada akhirnya dapat memicu timbulnya keluhan sistem pernafasan.Status gizi (IMT) pada 
kelompok terpapar sama dengan kelompok tidak terpapar, yaitu status gizi normal (IMT 18,524,99) masing-masing berjumlah 24 responden $(75 \%)$ dan status gizi tidak normal (IMT <18,5 atau $\geq 25$ ) masing- masing berjumlah 8 responden $(25 \%)$.

\section{c. Lama Pajanan}

Tabel 4.4 Distribusi Frekuensi Lama Pajanan

\begin{tabular}{lc}
\multicolumn{1}{c}{ Kelompok } & $\begin{array}{c}\text { Rata }- \text { Rata } \\
\text { (tahun) }\end{array}$ \\
\hline Terpapar & 2.88 \\
\hline Tidak Terpapar & 2.84 \\
\hline
\end{tabular}

Waktu responden melakukan aktivitas di daerah yang membuat menurunnya kesehatan akibat paparan yang di hasilkan oleh industry di daerah itu. Kemampuan mengeluarkan partikel debu terhirup ini menyebabkan waktu tinggal partikel debu yang terhirup di dalam paru paru menjadi lebih singkat (Darmono,2010). Hasil survey 64 responden yang di kelompokan menjadi 2 yaitu terpapar 32 responden dan tidak terpapar 32 responden data di dapatkan dengan wawancara didapati nilai rata rata untuk kelompok terpapar yaitu 2.88 jam dan kelompok yang tidak terpapar 2.84 jam.Keluhan penyakit saluran pernafasan sangat berkaitan dengan waktu pajanan terhadap partikel debu terhirup.semakin lama responden berada di kawasan bahan berbahaya maka semakin besar asupan berbahaya yang di terima (Khumaidah,2009).

\section{d. Frekuensi Pajanan}

Tabel 4.5 Distribusi Frekuensi Pajanan

\begin{tabular}{lcc} 
Kelompok & $\begin{array}{c}\sum \text { frekuensi pajan } \\
\text { Hari /tahun }\end{array}$ & $\begin{array}{c}\text { Rata - Rata } \\
\text { (hari/tahun }\end{array}$ \\
\hline Terpapar & 11550 & 360.94 \\
\hline Tidak & 11365 & 355.16 \\
Terpapar & & \\
\hline
\end{tabular}

Frekuensi pajananmkelompok terpapar de Tingkat keseringan pajanan PM10 yang di alamiresponden per hari yang di hitung selama satu tahun setelah di kurangi lama responden meninggalkan rumah.nilai frekuensi di ambil dari nilai rata-rata (mean) yaitu terbagi menjadi dua kelompok terpapar dan tidak terpapar. Pada kelompok terpapar di ketahui nilai rata rata 361 hari/tahun dan yang tidak terpapar 355 hari/tahun.Kebanyakan untuk responden yang di wawancarai adalah ibu rumah tangga.ataupunpedagang yang kerja di area semen $X$ yang dimana mereka melakukan aktivitas \pm 20 jam bila di bandingkan dengan anak sekolah yang dirumah hanya 15 jam. Batas Frekuensi Pemajanan yaitu untuk yang terpapar $\leq 250$ hari/tahun dan yang untuk yang tidak terpapar 250 hari/tahun. Cara untuk menghitung frekuensi pemajanan yaitu berapa lama responden melakukan aktivitas di daerah berbahaya di kalikan berapa banyak minggu/bulan dan dikalikan berapa hari/tahun. Dari hasil data penelitian 64 responden melakukan kegiatan sehari-hari kebanyakan di sekitar daerah yang berbahaya akan terpaparnya partikel yang terhirup (PM10).ngan jumlah responden 32 orang didapatkan hasil jumlah frekuensi pajanan 11550 hari/ tahun dengan nilai rata rata yaitu 361 hari/ tahun dan pada kelompok tidak terpapar dengan jumlah responden 32 orang didapatkan hasil jumlah frekuensi pajanan 11365 hari/ tahun dengan nilai rata - rata yaitu 355 hari/ tahun.

e. Status Merokok

Tabel 4.6 Persentase Status Merokok

\begin{tabular}{lcccc}
\hline \multicolumn{1}{c}{$\begin{array}{c}\text { Status } \\
\text { merokok }\end{array}$} & \multicolumn{2}{c}{$\begin{array}{c}\text { Kelompok } \\
\text { Terpapar }\end{array}$} & $\begin{array}{c}\text { Kelompok Tidak } \\
\text { Terpapar }\end{array}$ \\
\cline { 2 - 5 } n & Presentase & n & Presentase \\
\hline $\begin{array}{l}\text { Bukan } \\
\text { Perokok }\end{array}$ & 15 & $46,9 \%$ & 16 & $50 \%$ \\
\hline $\begin{array}{l}\text { Perokok } \\
\text { Ringan }\end{array}$ & 12 & $37,5 \%$ & 12 & $37.5 \%$ \\
\hline $\begin{array}{l}\text { Perokok } \\
\text { Berat }\end{array}$ & 5 & $15.6 \%$ & 4 & $12.5 \%$ \\
\hline Jumlah & 32 & $100 \%$ & 32 & $100 \%$ \\
\hline
\end{tabular}

Status merokok didefinisikan sebagai kebiasaan merokok responden.Hasil analisis distribusi responden berdasarkan status merokok di ketahui bahwa sebagian besar responden adalah perokok.Distribusi status merokok pada responden yang terdistribusi merata pada masing-masing kelompok.Responden yang memiliki kebiasaan merokok sebanyak 33 responden dan responden yang tidak merokok sebanyak 31. Kebiasaan merokok sangat mempengaruhi pembersihan mukosiliaris saluran pernapasan serta membentuk sekresi yang lebih kental dan lengket (sabiston,1995). Merokok menyebabkan lebiih dari 4000 zat kimia berefek langsung pada sistem pernafasan sehingga perokok akan mengalami batuk kronis,peningkatan produksi spuntum,dan penurunan kaasitas paru.Kesemua hal tersebut dapat memperberat keluhan penyakit pernafasan. Status merokok pada kelompok terpapar dengan jumlah responden 32 orang didapatkan hasil yaitu 
terdapat 15 responden $(46,9 \%)$ bukan perokok, 12 responden $(37,5 \%)$ perokok ringan dan 5 responden $(15,6 \%)$ perokok berat. Sedangkan pada kelompok tidak terpapar dengan jumlah responden 32 orang didapatkan hasil yaitu terdapat 16 responden $(50 \%)$ bukan perokok, 12 responden $(37,5 \%)$ perokok ringan dan 4 responden $(12,5 \%)$ perokok berat.

f. Riwayat Penyakit Pernafasan Responden

Tabel 4.7 Persentase Riwayat Penyakit Pernafasan Responden

\begin{tabular}{lcccc}
\hline \multirow{2}{*}{$\begin{array}{c}\text { Jenis } \\
\text { kelamin }\end{array}$} & $\begin{array}{c}\text { Kelompok } \\
\text { Terpapar }\end{array}$ & $\begin{array}{c}\text { Kelompok Tidak } \\
\text { Terpapar }\end{array}$ \\
\cline { 2 - 5 } & n & Presentase & n & Presentase \\
\hline Ada & 8 & $25 \%$ & 5 & $15,6 \%$ \\
\hline Tidak Ada & 24 & $75 \%$ & 27 & $84,4 \%$ \\
\hline Jumlah & 32 & $100 \%$ & 32 & $100 \%$ \\
\hline
\end{tabular}

Riwayat penyakit pernafasan didefinisikan sebagai kondisi pernah atau sedang di diagnose satu atau lebih penyakit berikut diantara lain ISPA,alergi,TBC,bronchitis dan enfisma.Pada penelitian ini sebagian respoden memiliki riwayat penyakit pernafasan.Riwayat penyakit pernafasan berkaitan dengan penurunan kualitas otot pernafasan.Kualitas otot-otot pernapasan berbanding lurus dengan permeabilitas saluran pernafasan.Permeabilitas saluran pernafasan yang terganggu dapat berakibat pada menurunya fungsi organ pernafasan.Penurunan fungsi pernafasa inilah yang dapat mengakibatkan keluhan penyakut pernafasan. Riwayat penyakit pernapasan pada kelompok terpapar dengan jumlah responden 32 orang didapatkan hasil yaitu terdapat 8 responden $(25 \%)$ memiliki riwayat penyakit pernapasan dan 24 responden $(75 \%)$ tidak memiliki riwayat penyakit pernapasan. Sedangkan pada kelompok tidak terpapar dengan jumlah responden 32 orang didapatkan hasil yaitu terdapat 5 responden $(15,6 \%)$ memiliki riwayat penyakit pernapasan dan 27 responden $(84,4 \%)$ tidak memiliki riwayat penyakit pernapasan.

\section{g. Keluhan Sistem Pernapasan}

Tabel 4.8 Persentase Keluhan Sistem Pernafasan

\begin{tabular}{ccccc}
\hline $\begin{array}{c}\text { Keluhan } \\
\text { Sistem }\end{array}$ & \multicolumn{2}{c}{$\begin{array}{c}\text { Kelompok } \\
\text { Terpapar }\end{array}$} & \multicolumn{2}{c}{$\begin{array}{c}\text { Kelompok Tidak } \\
\text { Terpapar }\end{array}$} \\
\cline { 2 - 5 } Pernapasan & $\mathbf{n}$ & Presentase & n & \multicolumn{1}{c}{ presentase } \\
\hline Ada & 21 & $65,6 \%$ & 11 & $34,4 \%$ \\
\hline Tidak ada & 11 & $34,4 \%$ & 21 & $65,6 \%$ \\
\hline Jumlah & 32 & $100 \%$ & 32 & $100 \%$ \\
\hline
\end{tabular}

Pada penelitian ini keluhan sistem pernafasan didefinisikan sebagai hasil dari interprestasi keadaan ada atau tidaknya gejala dan faktor pencetus keluhan sistem pernafasan yang dialami oleh responden yang diukur dengan bantuan kuisoner yang telah tervalidasi dan reliable.Pada kuesioner terdapat pertanyaan terkait dengan keluhan sistem pernafsan dan pertanyaan di beri kode 0 (tidak) dan 1 (ya).Data rekap keluhan sistem pernafasan di kumpulkan oleh peneliti dari hasil wawancara kepada 64 responden yang terbagi menjadi 2 kelompok yaitu terpapar dan tidak terpapar.

Keluhan sistem pernafasan tidak hadir dengan sendirinyaTerdapat faktor-faktor yang melatarbelakangi seseorang mengalami keluhan sistem pernafasan.Faktor-faktor tersebut terdiri dari faktor eksternal seperti pajanan debu terhirup $\left(\mathrm{PM}_{10}\right)$.selain itu,terdapat pula faktor internal yang merupakan karakteristik individu (jenis kelamin,status gizi,lama pajanan,frekuensi permajanan,status merokok,riwayat penyakit pernafasan). Keluhan Sistem Pernafasan menunjukan bahwa Keluhan sistem pernapasan pada kelompok terpapar dengan jumlah responden 32 orang didapatkan hasil yaitu terdapat 21 responden $(65,6 \%)$ memiliki keluhan sistem pernapasan dan 11 responden $(34,4 \%)$ tidak memiliki keluhan sistem pernapasan. Sedangkan pada kelompok tidak terpapar dengan jumlah responden 32 orang didapatkan hasil yaitu 11 responden $(34,4 \%)$ memiliki keluhan sistem pernapasan dan 21 responden $(65,6 \%)$ tidak memiliki keluhan sistem pernapasan.

\section{Analisis Multivariate}

1. Seleksi Bivariat

Bila hasil analisis bivariat antara variabel independen dan variabel dependen menghasilkan nilai $\mathrm{p}<0,25$ maka variabel independen tersebut dimasukkan ke tahap analisis multivariat, seperti tabel berikut ini :

Tabel 4.9 Hasil Seleksi Bivariat

\begin{tabular}{|c|c|c|}
\hline Variabel Independen & $n \quad$ Nilai p & Keterangan \\
\hline Intake $\mathrm{PM}_{10}$ & 0,044 & Kandidat \\
\hline Jenis Kelamin & 0,316 & Bukan Kandidat \\
\hline Status Gizi (IMT) & 1 & Bukan Kandidat \\
\hline Lama Pajanan & 0,223 & Kandidat \\
\hline Frekuensi Pajanan & 0,236 & Kandidat \\
\hline Status Merokok & 0,453 & Bukan Kandidat \\
\hline Riwayat peyakit & 0,026 & Kandidat \\
\hline
\end{tabular}

Uji Regresi Logistik Sederhana

Tabel 4.9 menunjukkan bahwa variabel independen yang menjadi kandidat untuk dimasukkan ke uji regresi logistik ganda adalah variabel yang memiliki nilai $\mathrm{p}<0,25$ yaitu variabel 
intake $\mathrm{PM}_{10}$, lama pajanan, frekuensi pajanan, dan riwayat penyakit.

2. Analisis Pengaruh Intake $\mathbf{P M}_{10}$ Terhadap Keluhan Sistem Pernapasan

Apabila hasil analisis regresi logistic ganda antara variabel independen dan variabel dependen menghasilkan nilai $\mathrm{p}>0,05$ maka variabel independen tersebut dikeluarkan dari pemodelan multivariate hal tersebut dilakukan sampai tidak ada variabel independen yang layak untuk dikeluarkan dari pemodelan multivariate.

\begin{tabular}{ccc}
\begin{tabular}{c} 
Tabel 4.10 \\
\multicolumn{1}{c}{$\begin{array}{l}\text { Hasil analisis } \\
\text { PM}_{10} \text { Terhapapan }\end{array}$}
\end{tabular} & $\begin{array}{r}\text { Pengaruh } \\
\text { Keluhan }\end{array}$ & $\begin{array}{r}\text { Intake } \\
\text { Sistem }\end{array}$ \\
\hline Variabel & Nilai P & PR \\
\hline Intake PM ${ }_{10}$ & 0,048 & 2,778 \\
\hline Lama Pajanan & 0,244 & 2,778 \\
\hline Frekuensi Pajanan & 1 & 0,000 \\
\hline Riwayat Penyakit & 0,039 & 4.394 \\
\hline
\end{tabular}

Uji Regresi Logistik Berganda

Tabel 4.10 menunjukkan bahwa variabel memiliki kandidat nilai $\mathrm{p}$ (nilai $\mathrm{p}<0,25$ ) nilai PR menunjukan nilai risiko Terdapat 4 variabel yaitu intake $\mathrm{PM}_{10}$, lama pajanan,frekuensi pajanan dan riwayat penyakit.Variabel yang paling dominan mempengaruhi keluhan sistem pernapasan adalah riwayat penyakit (karena Nilai PR paling besar di antara variabel lainnya).

Tabel 4.11 Hasil Akhir Analisis Pengaruh Intake $\mathrm{PM}_{10}$ Terhadap Keluhan Sistem Pernapasan

\begin{tabular}{lcc}
\hline \multicolumn{1}{c}{ Variabel } & Nilai P & PR \\
\hline Intake PM 10 & 0,048 & 2,778 \\
\hline Riwayat Penyakit & 0,039 & 4.394 \\
\hline
\end{tabular}

Uji Regresi Logistik Berganda

Tabel 4.11 menunjukkan bahwa variabel memiliki kandidat nilai $\mathrm{p}$ (nilai $\mathrm{p}<0,05)$ nilai PR menunjukan nilai risiko Terdapat 2 variabel yaitu intake $\mathrm{PM}_{10}$ dan Riwayat Penyakiit Pernapasan dimana nilai intake $\mathrm{PM}_{10}$ nilai $\mathrm{p}=0,048$ dengan nilai PR 2,778 dan riwayat penyakit pernapasan nilai $\mathrm{p}=$ 0,039 dengan nilai PR 4,394.

3. Pengaruh variabel terhadap keluhan sistem pernapasan. a. Pengaruh Intake Pajanan Debu PM10 Terhadap Keluhan Sistem Pernafasan

Hasil analisis multivariate menunjukan bahwa pajanan debu terhirup $\left(\mathrm{PM}_{10}\right)$ memiliki hubungan yang dominan terhadap keluhan sistem pernafasan.Interpretasi ada pengaruh signifikan antara Independen dan dependen karena $P$ value $<$ alpha 0,05 $(\mathrm{P}=0,048)$ kecenderungan meningkatnya intake PM10 berpengaruh positif terhadap terjadinya risiko keluhan sistem pernafasan. Pengaruh dimana setiap peningkatan intake $1 \mathrm{mg} / \mathrm{kg} / \mathrm{hari}$ akan menyebabkan risiko terjadinya keluhan kesehatan sistem pernafasan sebesar 2,778 kali .Penelitian ini sejalan dengan penelitian yang di lakukan oleh merpaung (2012) yang menyatakan bahwa asupan atau intake partikel debu terhirup (PM10) memiliki pengaruh pengaruh terhadap keluhan Asma (Keluhan Sistem Pernafasan).

b. Pengaruh Riwayat Penyakit Pernafasan Terhadap Keluhan Sistem Pernafasan

Berdasarkan analisis sebagian responden yang mengalami keluhan sistem keluhan pernafasan adalah yang memiliki riwayat penyakit pernafasan di ketahui bahwa terdapat hubungan yang signifikan antara riwayat penyakit dengan keluhan sistem pernafasan.Pada penelitian Soedjono (2002) dimana riwayat penyakit pernafasan dapat meninggkatkan risiko hingga dua kali lebih besar.Interpretasi ada pengaruh signifikan antara Independen dan dependen karena $\mathrm{P}$ value < alpha 0,05 $(\mathrm{P}=0,039)$ kecenderungan adanya riwayat penyakit pernapasan pada responden berpengaruh positif terhadap terjadinya risiko keluhan sistem pernafasan Hasil uji statistik menyimpulkan setiap peningkatan adanya responden yang memiliki riwayat penyakit pernafasan akan menyebabkan risiko terjadinya keluhan sistem pernafsab sebesar 4,394 kali.

\section{SIMPULAN DAN SARAN}

\section{Simpulan}

Pengaruh pajanan PM10 di udara terhadap keluhan sistem pernafasan masyarakat Semen $X$ ada empat variabel yang menjadi kandidat yaitu intake debu $\mathrm{PM}_{10}$ dan Riwayat Penyakit Pernafasan dimana nilai $\mathrm{p}$ value < alpha 0,05 .

a. Pengaruh dimana setiap peningkatan intake 1 $\mathrm{mg} / \mathrm{kg} /$ hari akan menyebabkan risiko terjadinya keluhan kesehatan sistem pernafasan sebesar 2,778 kali.

b. setiap peningkatan adanya responden yang memiliki riwayat penyakit pernafasan akan menyebabkan 
risiko terjadinya keluhan sistem pernafasan sebesar 4,394 kali.

\section{Saran}

a. Masyarakat melakukan pemasangan barrier / kain kasa pada setiap ventilasi rumah untuk menangkal partikulat masuk kedalam rumah.

b. Masyarakat melalui organisasi di tingkat RT RW mengajukan program pengendalian risiko lingkungan dengan penanaman vegetasi di sekeliling Pabrik Semen X untuk meminimalisir dampak pajanan debu ke area pemukiman.

\section{DAFTAR PUSTAKA}

Agus, and Budi. 2006. Pengukuran Partikel Udara (TSP, PM10, dan PM2,5) di sekitar Calon Lokasi PLTN Semenanjung Lemahabang. AMDAL Report. Jakarta: Pusat teknologi Limbah radioaktif-BATAN

Atrisman, Abdurahman, S. W. 2005. Analisis dan manajemen risiko kesehatan pencemaran udara. Jurnal Ekologi Kesehatan Vlol 4.

ATSDR."Public Health Assessment Guidance Manual."http://www.atsdr.cdc.gov/hac/PHSM anual/toc.html.2005.(accessedDesember28des ember2017).Bustan, M.N.

Darmono, 2010 lingkunggan Hidup dan Pencemaran : Hubungannya dengan toksikologi Senyawa Logam. Jakarta :UI Perss.

Depkes RI, 2007. Laporan Riset Kesehatan Dasar Tahun 2007. Jakarta: Balai Litbang.

, 2012. Pedoman Analisis Risiko Kesehatan Lingkungan (ARKL) Jakarta Direktorat Jenderal P2PL kementrian Kesehatan Republik Indonesia.

Gatot Suhariyono,2010 Perkiraan Deposisi Partikel Udara (PM10 / PM2,5 DAN TSP) Pada Saluran Pernapasan Penduduk Cilegon Menggunakan PerangkatLunak LUDEP.

Gehrdan Heyder.(2000). Particle Lung Interaction .NewYork: Marcel Dekker,Inc. NRC."Risk Assessmentin The Federal Government: Managing The Process. "http://www.nap.edu/catalog/366.html.1983.(a ccessed Desember (U. Indonesia, Kotouki, Masyarakat, Studi, \& Kesehatan, 2012)29, 2017)
Indonesia, M. K. R. 2003. Peraturan. Digitized by USU Digital Library, 18. https://doi.org/10.1017/CBO9781107415324.0 04

, U., Kotouki, A., Masyarakat, F. K., Studi, P., $\&$ Kesehatan, S. 2012. Universitas Indonesia.

Khairiah.2012.Analisis Konsentrasi Debu Dan Keluhan Kesehatan Pada Masyarakat Di Sekitar Pabrik Semen Di Desa Kuala Indah Kecamatan Sei Suka Kabupaten Batu Bara Tahun 2012, Medan:USU.http://repository.usu.ac.id/bitstrea m/123456789/35251/4/Chapter\%20II.pdf

Kolluru , et al., 1996. Risk Assesment and Managemen Handbook. New York : McGrawhill inc

Louvar, J.F., and B.D. Louvar. 1998. Health and Environmental Risk Analysis : Fundamental with Application. New Jersey: Prentice Hall

Marpaung, Y . M., 2012. Pengaruh Pajanan Debu Respirabel Terhadap Kejadian Gangguan Fungsi Paru Pada Pedagang Tetap Di Terminal Terpadu Kota Depok Tahun 2012 (Skripsi).Depok : FKM Universitas Indonesia.

Murdiyarso, \& Daniel. 2003. Udara ambien - Bagian 6: Penentuan lokasi pengambilan contoh uji pemantauan kualitas udara ambien.

Novisa, R., \& Ahmadi, U. F. (2012). Analisis Risiko Pajanan PM2, 5 di Udara Ambien Siang Hari terhadap Masyarakat di Kawasan Industri Semen. Jurnal Kesehatan Masyarakat Nasional, 7(4), 173-179.

Randy Novirsa and Achmadi , 2012. Analisis Risiko Pajanan PM 2,5 di Udara Ambien Siang Hari terhdap Masyarakat di Kawasa Industri Semen.

Republik Indonesia 2002.Keputusan Menteri Kesehatan RepublikIndonesia Nomor 1405/Menkes/SK/XI/2002 Tentang Persyaratan Kesehatan Lingkungan Kerja Perkantoran Dan Industri.

2002. Peraturan Pemerintah No. 41 Tahun 1999 Tentang Pengendalian Pencemaran Udara.

Simanjuntak, M. L., Pinontoan, O. R., \& Pangemanan, J. M. 2015. Hubungan Antara Kadar Debu, Masa Kerja, Penggunaan Masker Dan Merokok Dengan Kejadian Pneumokoniosis 
Pada Pekerja Pengumpul Semen Di Unit Pengantongan Semen PT . Tonasa Line Kota Bitung Relationship Between Level Of Dust, Work Period, Use Of Mask And Sm. Jikmu, 5(2b), 520-532.

Slamet Riyadi.1982. Pencemaran Udara. Surabaya : Usaha Nasional

Universitas, P., \& Ratulang, S. 2013. Analisis Risiko Kesehata Partikel Debu Total Terhadap Risiko Penyakit Infeksi Saluran Pernapasan Akut ( Ispa) Di Kota Salakan Pendahuluan Dewasa ini pencemaran udara telah menjadi masalah kesehatan lingkungan utama di dunia, khususnya di negara berkemba, 1 .
Tonasa Line Kota Bitung Relationship Between Level Of Dust, Work Period, Use Of Mask And Sm. Jikmu, 5(2b), 520-532.

Universitas, P., \& Ratulang, S. 2013. Analisis Risiko Kesehata Partikel Debu Total Terhadap Risiko Penyakit Infeksi Saluran Pernapasan Akut (Ispa) Di Kotasalakan Pendahuluan Dewasa ini pencemaran udara telah menjadi masalah kesehatan lingkungan utama di dunia, khususnya di negara berkemba, 1. 